\title{
British Music Industry: A Case Study In Music Piracy
}

Kamlesh T. Mehta, Peace College, USA

\begin{abstract}
The case study is about loss of business due to piracy and file-sharing in the music industry in Britain. According to a survey by Ipsos Inc. (2006), CD piracy cost the industry $£ 165 m$ in lost revenue in 2005 - nearly 10\% of total sales. The survey found that 37 million pirated CDs were sold in Britain in 2005. The piracy of music in Britain has pinned the British Music Industry (BMI) and the music artists against the internet service providers, the government and the consumers. The BMI is blaming the Internet Service Provider (ISP) firms for not policing illegal downloads of music and asked them to disconnect people who ignore requests to stop sharing music. The ISP firms do not see their role as policing the piracy problem and do not agree with BMI. The BMI is pressuring the government to legislate copyright offenses related to music downloads in Britain. Also, the BMI wants the consumers engaged in copyright offense of music piracy to be prosecuted for criminal offense in addition to civil offenses. The consumers disagree with the BMI. The case study discusses the current actions of the BMI, ISPs and the British Government.
\end{abstract}

Keywords And Subjects: Music Industry, Music Piracy, CD Piracy, Illegal Music Downloads, File-Sharing, Intellectual Property Protection, Market Growth, Market Share, Legal Issues, Consumer Rights, Political Environment, British Music Industry, British Government, Internet Service Provider Firms, Consumers, and Public Relations.

\section{THE DILEMMA}

$\varnothing$ upiter Research (2008) estimates that sales of digital music downloads exceeded \$1.1 billion in 2007 and will grow rapidly (39 percent) in 2008 to reach $\$ 1.6$. The British Music Industry (BMI) is fed-up with the piracy and illegal file-sharing of music in Britain. According to a survey by Ipsos Inc. (2006), CD piracy cost the industry $£ 165$ million in lost revenue in 2005 - nearly $10 \%$ of total sales. Car boot sales and markets accounted for over a third of pirated CDs, while a quarter were bought from friends. The survey found that 37 million pirated CDs were sold in Britain in 2005, the value of which was more than the combined legal sales of the leading 13 albums in Britain. It is the first time the industry has estimated the projected losses caused by pirated CDs.

The piracy and counterfeit of music in Britain has pined the British Music Industry and the music artists against the internet service providers, the government and the consumers. The BMI is blaming the internet service providers for not policing illegal downloads of music and has asked them to disconnect people who ignore requests to stop sharing music. The BMI wants all ISP firms to participate in agreements that would require ISP to "educate" their customers and enforce "Three Strikes" policy to curb music piracy. According to a "Three Strikes" policy, BMI will identify and monitor the customers engaged in illegal downloading and have the ISP firms sent out three warnings. After three warnings, if the customers do not stop illegal downloading, their net connection will be discontinued. The Internet Service Provider firms do not see their role as policing the piracy problem and do not agree with BMI. The BMI is pressuring the government to legislate copyright offenses related to music downloads in Britain. Also, the BMI wants the consumers engaged in copyright offense of music piracy to be prosecuted for criminal offense in addition to civil offenses. The consumers disagree with the BMI. 


\title{
THE PARTIES AND THEIR POSITIONS IN THE CONFLICT
}

\author{
British Music Industry (BMI)
}

According to British Music Industry, more than six and a half million people in Britain illegally access and distribute music. Independent research has shown time after time that people who download illegally generally spend less on music than people that don't, which undermines investment in new music. BMI attributes the increase in piracy to the piecemeal enforcement by the government. According to BMI, owners of markets where counterfeits are sold should be prosecuted. In addition, BMI wants stricter financial punishment for counterfeiters in order to have a sufficient deterrent effect in civil cases. BMI would like to see the trading standards officers granted the duty, power and resources to tackle copyright offences. BMI is of the opinion that the police and trading standards officers are operating with very limited resources.

Also, the BMI attributes the problem of piracy to ISPs. According to the BMI, ISPs have done little or nothing to address illegal downloading via their networks. The BMI has asked internet service providers to disconnect people who ignore requests to stop sharing music and expects the ISP firms to educate their customers not to steal music. According to BMI, at the heart of this issue is ensuring that creators are fairly rewarded in the digital age and working in partnership with ISPs to develop first-class, safe, legal, digital music services is the way forward. According to BMI, ISPs are in a unique position to make a difference and in doing so to reverse a culture of creation-without-reward that has proved so damaging to the whole music community over the last few years.

The BMI representative is of the opinion that any socially responsible ISP should, as a core part of its business, put in place steps to help their customers avoid engaging in illegal activity, and deter those who knowingly break the law. BMI believes that if the ISPs do not help with the fight against music piracy, then the government will bring in legislation to make them cooperate which may include legal sanctions against the ISP firms. In addition, some in the British Music Industry believe that the government is considering a "three strikes" approach to tackling persistent offenders in the report. If the government goes ahead, Britain would be one of the first countries to impose sanctions.

\section{Music Artists}

The music artists want an end to piracy and have urged the ISPs to help end illegal music downloads. The manager of the $\mathrm{U} 2$ called for policies on disconnecting internet of those who acquired tracks illegally, using a speech in France to urge governments to take action. Also, the music artists want the ISP firms to share the revenues they made out of music. As a result of the actions of the manager of U2, France is working toward a legal system that promotes a policy of disconnecting internet of those who acquire music tracks illegally. The manager of U2, at a conference in Cannes, urged the artists to stand up against what he called the "shoddy, careless and downright dishonest way they have been treated in the digital age".

In Britain, the music artists have compared the illegal download of music to other forms of illegal acquisitions. For example, advertising stolen cars, handling the money for stolen cars and seeing to the delivery of stolen cars, would be subjected to legal actions. Another example is stealing a laptop or not paying for the broadband service leading to service cut off.

\section{British Government}

The record labels and governments agree that ISPs should not be responsible for what passed along their networks. However, in October 2008, the British government called on ISPs to take a "more activist role" in the problem of illegal file-sharing. A draft government consultation document suggests ISPs should be drafted in to the fight against piracy. It suggested that people who persistently download and share copyrighted material could have their net access removed. The proposal is aimed at tackling the estimated 6 million broadband users in Britain who download files illegally every year. According to the proposal, consultation would begin in spring and legislation could be implemented by mid-year 2009 . 
Although the government has no burning desire to legislate the actions of ISPs the proposal signals a change of tone from the government. The intentions of the government and the proposal are outlined in a creative industries strategy paper called Creative Britain: New Talents for the New Economy. The document is a broad ranging paper that sets out government support for the creative industries. In particular, any legislation would have to take account of the 2002 E-Commerce Regulations that define net firms as "conduits" which are not responsible for the contents of the traffic flowing across their networks. European laws on online privacy could also create problems for any new legislation.

The government denies rumors that the government was considering a "three strikes" approach to tackling persistent offenders in the report. According to the government representative such a strategy had never been in the paper. However, the industry has been given until spring of 2009 to find a solution to illegal down-loaders or face legislation. Also, the government has started a consultation exercise that could result in laws that force net firms to tackle music piracy. A working group will be set up under the auspices of regulator Ofcom to look at effective measures to tackle persistent file-sharers.

\section{Internet Service Provide (ISP) Firms}

The Internet Service Providers have maintained that it is not their job to be an 'internet policeman' and criticized the BMI for demanding that the ISPs act against pirates by disconnecting people who ignore requests to stop sharing music. The ISPs consider BMI's demands as unreasonable and unworkable. The ISP firms maintain the position that they are the conduit that gives users access to the internet. They do not control the internet, nor do they control what their users do on the internet. Therefore, ISPs cannot foresee any circumstances in which they would voluntarily disconnect a customer's account on the basis of a third party alleging a wrongdoing. ISPs would fight to protect the rights of its users using the law.

The record labels and governments agree that ISPs should not be responsible for what passed along their networks. The ISP Association has always maintained that it cannot be held responsible for illegal peer-to-peer traffic because it is "merely a conduit" of such material according to the 2002 E-Commerce Regulations. Therefore, the legal and technical barriers prohibit the ISPs from being anything other than a "mere conduit" and they are not responsible for the contents of the traffic flowing across their networks. In addition, other laws on surveillance explicitly prohibit ISPs from inspecting the contents of data packets unless forced to do so by a warrant. The technical issues also made it hard for ISP firms to take action against specific types of traffic. For instance, while some people use peer-to-peer networks to download copyrighted material many commercial services, such as Napster and the BBC's iPlayer, use file-sharing technology to distribute music and TV legally. Creating appropriate legislation would be very difficult. Any scheme has got to be legal, workable and economically sustainable. ISPs were already pursuing self-regulation, which was the government's preferred route.

The ISPs acknowledge that they are involved in traffic management but that is to optimize the service for all their customers. The ISPs take actions against any customer whose usage exceeds a limit associated with their tariff. The ISP firms manage their bandwidth in many different ways. Some firms happily let a customer use as much as she/he likes but will charge her/him accordingly. Others impose charges on customers who regularly exceed their download limits and a few manage their system so users cannot exceed a monthly download cap.

\section{Consumers}

The consumers do not agree with BMI's perspectives and do not want to buy music in expensive shops since they do not have that much money to spend on music. Some customers argue that they were "getting their own back" from the music industry's greed. There is a sense among consumers that the record industry goes too far in milking customers and retailers dry with high prices and increased profits. Customers argue that they should not have to pay again and again for a music album, especially at a full price, when they already bought it on LP, eighttrack, cassette, and CD. The practices of BMI are not going to deter customers from sharing a CD with a next-door neighbor over the fence. 
In June 2008, The BMI and one of the prominent firms, Virgin Media, entered in to an agreement to tackle the problem of music piracy through consumer education by identifying and writing to customers whose net connection may have been used to download unlicensed content. The possibility of account suspension, and the ultimate sanction of contract cancellation, will follow for those customers who choose not to take the advice and rectify the illegal downloading or file-sharing of music. Also, some consumers received written correspondence warning them that legal actions could be taken against them.

Customers have viewed BMI's position and Virgin Media's actions unfair and unjust and regard them as driven by greed. Some customers are unhappy with Virgin Media and believe that the strategies used by the company are doomed to fail. Virgin Media will lose a lot of customers over this because people don't like to be accused of stealing music. The actions of Virgin Media made some feel betrayed. Consumer rights group find the written correspondence a disproportionate response from the music industry and see the need to protect users from punitive measures. The music industry is in a position of offering a viable alternative before it clamps down on the activities of some users.

\section{ENFORCEMENTS AND IMPLICATIONS}

\section{BMI and ISP Partnership}

BMI is pushing for increase in licensed music services and decrease in illegal downloading by customers who cling to an implausible and dated belief that the internet will be an endless free "lunch". In 2008, 13.4\% of the sales revenues have come through digital platforms and in total, more than 200 million downloads have been sold in Britain. There are already hundreds of licensed online and mobile services (carrying more than six million tracks) from which to choose where and how to access music legally. iTunes (paid-for a la carte downloads), Napster and eMusic (monthly subscription), We7 (free to consumer, ad-supported), last.fm (interactive web radio), YouTube, Yahoo (streamed video on-demand) and Nokia's Comes With Music (music as part of a subscription) are just some of the many digital business models that record labels are supporting.

Despite the proliferation of licensed services, most music is still downloaded from unlicensed services - a problem that cannot be addressed through new models alone. BMI is fighting to promote and protect the value of copyright, to allow their new models space to breath. This is why ISP partnerships are of primary interest to BMI in the maturing digital music business. BMI believes that ISPs can become significant distributors of digital media and share in the tremendous value that would be unleashed if more music were accessed legally online.

In June 2008, The BMI and one of the prominent firms, Virgin Media, entered in to an agreement to tackle the problem of music piracy through consumer education by identifying and writing to customers whose net connection may have been used to download unlicensed content. BMI has worked hard at consumer education by sending hundreds of thousands of information messages to illegal file sharers, supporting initiatives such as ProMusic, developing free useful tools for consumers such as Digital File Check, and partnering with charities such as Childnet.

In this agreement, BMI will provide Virgin Media with publicly available information about their customers' illegal music sharing. Virgin Media then will contact the customer to give them the information they need to remedy the problem. Both the parties hope that most account holders will welcome information that helps them to download legally and avoid the risk of legal action or the cancellation of their contract. Although this will result in customers taking a note that their ISP is beginning to take the issue seriously and take the advice, it will not work for everyone. The BMI will collect and pass on to the ISP publicly available information about their customers' illegal file sharing, and ask them to send advisory letters as outlined above. The possibility of account suspension, and the ultimate sanction of contract cancellation, will follow for those customers who choose not to take the advice. BMI considers this a genuine step in the right direction, and a turning point in the music community's bid to restore value in music to its rightful owners: the artists and music companies who invest in their creative careers. The ISPs face a difficult balancing act between conforming to the BMI's new rules and pleasing their own customers. 


\section{Actions Against the Consumers}

The current system involves the BMI policing file sharing networks. It looks for illegal traffic and identifies the IP address from which it has come and informs the ISP. There is no distinction made between someone who has downloaded one illegal track and someone who has downloaded thousands. A joint letter from ISP and the BMI is then sent to the individual.

In a part of a 10-week campaign in conjunction with the BMI to "educate" users about downloads, Virgin Media sent about 800 letters to customers warning them that they should not be downloading illegal music files via the file-sharing sites. Virgin is keen to stress that the 800 or so letters it has so far sent are a drop in the ocean compared to its 3.8 million user base.

BMI wants all Britain ISPs to sign up to a so-called three strikes policy. A "three-strikes" system would see net connections of persistent pirates terminated if three warnings went ignored. So far only Virgin Media has officially signed up and it is keen to stress that currently it is running an education-only campaign and that no-one has been thrown off the network. Of the six of the Britain's biggest net providers, five-BT, Orange, Tiscali, BSkyB and Carphone Warehouse - firms have not agreed on a plan with the music industry to tackle piracy online. BMI has warned to take legal action, including taking ISPs to court, if they refuse to participate in the "education campaign" warning customers that they should not be downloading illegal music files via file-sharing sites.

\section{Legal Actions Against Top File-Sharing Company}

The Pirate Bay's servers do not store copyrighted material but offer links to the download location of films, TV programs, albums and software. The website is said to have between 10 and 15 million users around the world and is supported by online advertising. According to the Pirate Bay website, its users are currently downloading close to a million files.

The men who run one of the most popular file-sharing sites in the world, The Prate Bay, have been charged with conspiracy to break copyright law in Sweden. Plaintiffs MGM, Warner, Columbia Pictures, 20th Century Fox Films, Sony BMG, Universal and EMI hit the Pirate Bay with legal action. Police seized computers in May 2006, temporarily shutting down the website. According to the prosecutor, the website was commercially exploiting copyright-protected work because it was financed through advertising revenues. He added, the operators of The Pirate Bay have always been interested in making money, not music. The charges relate to 20 music files, nine film files and four computer game files. If convicted, the company men could face a maximum of two years in prison and pay for damages of 1.2 million kronor $(£ 90,000)$, the minimum amount the company men profited from the illegal activity, according to the prosecution.

On the company site, a statement says: "In case we lose the pending trial (yeah right) there will still not be any changes to the site. "The Pirate Bay will keep operating just as always. We have been here for years and we will be here many more." According to the CEO of Pirate Bay, it's okay to copy. The record companies get their money from so many places that the sales are just one small part. Some believe that Pirate Bay is being targeted because of its popularity, high-profile, and flagrant attitude in its actions.

The Russian music download site allofmp3.com, which sold songs at a fraction of the cost of other sites, is claimed to be the second biggest seller of music downloads after iTunes. It was the subject of countless lawsuits from Britain and US record labels that claimed it violated copyright law by selling songs without permission. Numerous lawsuits were also started against the site's owners MediaServices. In 2006, a lawsuit was filed on behalf of Arista Records, Warner Bros, Capitol and UMG recordings. Alsp, BMI filed similar lawsuits. According to the BMI, Allofmp3.com violated copyright law in Russia and internationally by ripping off artists and creators, taking music that it had no right to reproduce and selling it worldwide.

The site's owners, MediaServices, maintained the site was legal under Russian law and has subsequently set up a new service called mp3Sparks.com. Allofmp3.com maintained it paid royalties to a Russian licensing body and said that it made clear on its website that users should check copyright laws in their own country before using the 
site. Under increased pressure, Moscow finally signed an agreement to shut down the site and allofmp3.com site was closed. However, MediaServices has launched a new website that seems to offer a very similar service. Like allofmp3.com, mp3sparks.com warns customers to obey their own government's laws on downloading. It also claims that it is authorized to distribute music and pays license fees.

\section{DISCUSSION QUESTIONS}

1. In your opinion, is file-sharing an act of piracy? Is the downloading of music an act of piracy? Explain with reasons.

2. Should an act of file-sharing or downloading of music be treated as a criminal offence? Why? Should it be treated as a civil offence? Why?

3. Who are the parties to illegal download and upload of music on the net? Who should be blamed for the music piracy problem? Why?

4. Should the Net Firms or ISPs be held accountable for CD piracy activities of the net users in Britain? Please Explain.

5. Is it the responsibility of ISPs to serve as a police for music piracy? Why or why not?

6. Should government regulate the conduct of the ISPs and impose sanctions?

7. Should net based music be free to customers? Why?

8. Who is looking out for the customers against the greed of the multinationals in the music industry? What should the customers do?

9. What impact will the warning letters to file-sharers have on the music piracy? Is this an effective strategy to stop the piracy of music? Why?

10. Should the ISP firms participate in the "education campaign" proposed by the BMI? Why?

11. Should the ISP firms give-in to the bullying tactics of BMI and sign on the "three strikes" agreement to tackle piracy in England? Why?

12. Is Pirate Bay targeted with legal actions because it is popular, has a high profile, and is flagrant in its actions? Why are the small companies engaged in music piracy not targeted for legal actions?

\section{AUTHOR INFORMATION}

Dr. Kamlesh T. Mehta is an internationally renowned professor, research scholar, administrator, consultant, and business owner. He has been recognized in The National Faculty Directory (1998) and Harvard Business School Publishers-International Directory of Business and Management Scholars and Research (1996). Dr. Mehta's background includes Doctor of International Business and four other degrees in business. In his 18 years of academia and 20 years of international business experiences, Dr. Mehta's scholarly work has been published in SAM Advanced Management Journal, The Journal of Interdisciplinary Education, The Journal of Applied Business Research, The Journal of International Information Management, The Business Review-Cambridge, Industrial Management and Data Systems, The Midwest Review of International Business Research, The Journal of Technical Writing and Communications, and others. He has served as Study Abroad Program Director and organized several study abroad programs in the past. In addition, Dr. Mehta was elected as the President for Southwest Decision Sciences and Vice President for the Southwest Academy of International Business organizations. He has served as the Chair of the Department of Business Administration at various institutions and founded the Center for Global Business Studies. Dr. Mehta has reviewed numerous textbooks in International Business and Management for various publishers.

\section{REFERENCES}

1. "BPI demands action on pirate CDs". (2006). BBC News. http://news.bbc.co.uk/go/pr/fr//2/hi/business/5290944stm. Retrieved: January 12, 2007.

2. "Illegal Downloaders 'face UK band"”. (2008). BBC News. http://news.bbc.co.uk/2/hi/business/7240234.stm. Retrieved: March 12, 2008.

3. "ISPs could face piracy sanctions". (2008). BBC News. http://news.bbc.co.uk/go/pr/fr//2/hi/technology/7258437.stm. Retrieved: March 22, 2008. 
4. "Net firms in music pirates deal". (2008). BBC News. http://news.bbc.co.uk/go/pr/fr//2/hi/technology/7522334.stm. Retrieved: January 18, 2009.

5. "Pirate Bay hit with legal action". (2008). BBC News. http://news.bbc.co.uk/go/pr/fr//2/hi/technology/7219802.stm. Retrieved: February 31, 2008.

6. "Policing internet 'not ISP's job"'. (2008). BBC News. http://news.bbc.co.uk/go/pr/fr//2/hi/technology/7329801.stm. Retrieved: May 4, 2008.

7. $\quad$ Price, Matthew. (2002). "Belgrade fights CD pirates". BBC News. http://news.bbc.co.uk/2/hi/europe/2144588.stm. Retrieved: July 22, 2003.

8. "Russian download site shut down". (2007). BBC News. http://news.bbc.co.uk/go/pr/fr//2/hi/technology /6264266.stm. Retrieved: August 3, 2007.

9. $\quad$ "Selling Digital Downloads - A Report". (2008). Jupiter Research Inc. http://www.marketresearch.com/vendors/viewvendor.asp?vendorid=2544. Retrieved: January 18, 2009.

10. "Time to take on the file sharers". (2008). BBC News. http://news.bbc.co.uk/go/pr/fr//2/hi/technology/7452621.stm. Retrieved: July 13, 2008.

11. "U2 manager 'wants end to piracy". (2008). BBC News. http://news.bbc.co.uk/go/pr/fr//2/hi/entertainment/7215226.stm. Retrieved: February 29, 2008.

12. Ward, Mark, (2008). "Net firms reject monitoring role". BBC News. http://news.bbc.co.uk/go/pr/fr//2/hi/technology/7246403.stm. Retrieved: March 15, 2008.

13. "Warning letters to 'file-sharers"'. (2008). BBC News. http://news.bbc.co.uk/go/pr/fr//2/hi/technology/7486743.stm. Retrieved: January 18, 2009.

\title{
TEACHING NOTES
}

\author{
British Music Industry: A Case Study in Music Piracy \\ Dr. Kamlesh T. Mehta, Fraish Endowed Professor of International Business and Marketing and Chair of the \\ Business Program, Peace College, USA
}

\section{SYNOPSIS}

The case study is about loss of business due to piracy and file-sharing in the music industry in Britain. According to a survey by Ipsos Inc. (2006), CD piracy cost the industry $£ 165 \mathrm{~m}$ in lost revenue in 2005 - nearly $10 \%$ of total sales. The survey found that 37 million pirated CDs were sold in Britain in 2005. The piracy of music and file-sharing in Britain has pinned the British Music Industry (BMI) and the music artists against the internet service providers, the government and the consumers. The BMI is blaming the Internet Service Provider (ISP) firms for not policing illegal downloads of music and asked them to disconnect people who ignore requests to stop sharing music. The ISP firms do not see their role as policing the piracy problem and do not agree with BMI. The BMI is pressuring the government to legislate copyright offenses related to music downloads in Britain. Also, the BMI wants the consumers engaged in copyright offense of music piracy to be prosecuted for criminal offense in addition to civil offenses. The consumers disagree with the BMI. The case study discusses the current actions of the BMI, ISPs and the British Government.

\section{TEACHING SUGGESTIONS}

This case can be used in the class room for discussion or role play, as an outside project work, and as an examination case. The case is best used as a team assignment or role play and can be used in the teaching of intellectual property protection and international issues. The sections below provide suggested courses for the case and various suggestions for effective exploration of the issues brought forward in this case.

\section{Suggested Courses for the Case}

This case study is suitable for both the graduate and undergraduate courses in Principles of Management, Leadership in Business, Business Policy, Strategic Management, Marketing Management, Managing Across Cultures, Global Operations Management, International Business, Multinational Business, Global Business, Studies 
of the European Union, Business Law, Legal Environment of Business, Intellectual Property Protection Rights, Business Communications, Business Negotiation, International Relations, Political Science, and Public Relations.

\section{Case Study Issues}

This case study addresses the following issues:

1. Consumer rights;

2. Piracy of music in Britain;

3. $\quad$ Music piracy and legal consequences;

4. $\quad$ Position of the British Music Industry;

5. Role of the Internet Service Provider firms;

6. Position of the music artists;

7. Laws pertaining to music download in Britain;

8. $\quad$ Strategic Issues in Music Industry; and

9. Public relations

\section{OBJECTIVES OF THE CASE STUDY}

1. To understand the relationship dynamics among British Music Industry, Internet Service Provider Firms, The Government, Record Label Firms, and Consumers in Britain..

2. To examine the laws pertaining to music downloads and the legal consequences of music piracy in Britain.

3. To analyze the strategic issues in British Music Industry

4. To evaluate the roles and rights of the Internet Service Provider firms, the music artists, and the consumers in the music industry in Britain.

5. To assess the government actions to curtail music piracy in Britain.

\section{Additional Information}

Please contact the author of this case study to request for the detailed teaching notes and current developments in this case study. 